\title{
T.T. Cloete
}

\section{Simboliek in Totius se werk}

\begin{abstract}
Totius' works are not symbolic in the sense that they exhibit any affinity with or influence by the European Symbolism of the time. Nevertheless, much that is symbolic is found in his works. Although he was inclined to interpret the images and symbols in his own poems at times, and even wrote allegorical poems, he also wrote really good symbolic poems.

It emerged that the symbol has something universal, to such an extent that it is even possible to compile dictionaries of symbols, and the very fact that one can compile a dictionary of symbols, is sufficient proof that a symbol is not something particular but rather general. Many of the symbols used by Totius can be explained in the terms in which De Vries and Cirlot described these and similar symbols.

However valuable symbols may be in poetry, the merit of a poem lies in much more than in the symbol(s) occurring in it. Thus the symbolic poems by Totius are not automatically better than the poems which are less heavily symbolic. However, some of his best poems do constitute excelient symbolic poetry.
\end{abstract}

\section{Totius as Simbolis?}

Om van Totius as simbolis te praat, skep sekere probleme. As ons simbolis verstaan in die sin van die Europese (eintlik Franse) Simbolisme, dan is dit nie op hom van toepassing nie, al kon hy dalk op minder of meer direkte wyse van die Europese Simbolisme kennis geneem het, en al het hy 'n soort geestesverwantskap op natuurlike wyse met hulle in sekere opsigte gehad. Sy teoretiese opstel "Die digter as siener"* klink nogal simbolisties, omdat die Simboliste die digter as siener gesien het (Rimbaud, George), as priester

"Alle aanhalings uit Totius se werk kom uit Versamelde Werke 10. 
(Baudelaire), as iemand met 'n sogenaamde hoëre of dieper visie. Van die Simboliste se estetisisme, l'art pour l'art, dekandensie, eksotisme, melankolie, sensualisme, okkultisme en dergelike het Totius egter niks gehad nie, ook niks van hulle belangstelling in die Ooste, die naturalisme of positivisme nie. Die digter was vir Totius ook nie soos vir die Simboliste 'n buitestaanderfiguur nie. Inteendeel, as siener was die digter vir Totius profeet, dus bewustelik gerig op 'n gemeenskap. Ten slotte het Totius niks van die vernuwende, verdoeselende, dubbelsinnige tegnieke van die Simboliste gehad nie.

Selfs as ons die term simbolies in die gewone, omvattende betekenis gebruik, skep Totius vir ons probleme, al kry ons wel simboliek by Totius.

Totius is daarvoor bekend dat hy, veral in sy vroeëre werk, geneig was tot die allegoriese. Dink aan "Kindergraffies" in By die monument: die vaderland is 'n boomgaard, die moeders is die bome en die kindertjies van die vaderland is die bloeisels, en soos bloeisels het hulle doodgeryp. In hierdie (naiewe) gedig sien ons duidelik dat die allegorie nie alleen 'n 1:1-verhouding van beeld:saak is nie, maar bowendien 'n reeks verhoudings wat mekaar logies en analities in die tyd opvolg, terwyl die simbool 'n simultane hoeveelheid betekenisonderskeidinge is.

Op allerlei ander wyses was Totius geneig om 'n beeld saam met een of ander besinning te gee - in die gedig self. Dit gaan nie om besinning buite die teks om nie - dié kom by alle digters voor. Maar besinning in die gedig self is iets anders. En sodra die besinning in die gedig self opgeneem word as deel van die gedig, is die simboliek daarmee heen. Dan dra die digter 'n ekstra in wat die simboliek uithou en die saak laat uitloop op die vergelyking, of op die beeld met toepassing, soos in die bekende geval van "Die Godsbesluit" (Passieblomme) of op die allegorie.

\section{Simboliese gedigte by Totius}

Tog het Totius, van die begin af, simboliese gedigte geksryf, al het hy relatief miskien nie baie daarvan geskryf nie. Daar staan reeds so 'n gedig in sy debuutbundel, By die monument, naamlik "Daar kom hul":

En sla de moeder met de zonen. Gen. 32:II.

\section{Die Kind:}

Daar kom hul, daar kom hul oor heuwel en hang!

o Moeder, beskerm ons, nou word ons gevang!

Moeder:

My kinders, jul moeder verwag hul reeds lang;

en het al gebid al met heilige drang. 


\section{Kindertjies:}

Maar, moeder, daar kom hul met skuim aan die stang.

En ag, arme vader is lankal gevang!

Moeder:

My kinders, kom binne en wees nie meer bang:

die Vader daarbowe bestuur hulle gang.

Kindertjies:

Maar, moeder, hier is hul! o. Hoor die gedrang!

\section{Moeder:}

Wees stil maar, hul sal mos geen kindertjies vang!

Uit die bundelkonteks, onder andere, weet ons dit is 'n oorlogs- en nasionale gedig, maar die gedig self sê dit glad nie. Dit kan enige kindermoordgedig wees. In "Daar kom hul" word kinders doodgemaak, hulle sterf gewelddadig (lank voor die dood van die kinders van Passieblomme). "Daar kom hul" kan deur die leser, met goeie reg kragtens die kontekstuele informasie, as oorlogsen nasionale gedig gesien word, maar simbolies gesien, kan dit die (gewelddadige) dood van enige kind wees, in watter omstandighede, ruimte of tyd ook al. Daar is niks, behalwe die konteks, wat die gedig tot nasionale of oorlogsgedig maak en dus vereng nie. Die perde waarop die moordenaars ry, onder meer, maak die gedig simbolies van die dood in die algemeen. Ons weet uit die literatuur, uit die folklore, ook uit ander kunste, dat die dood 'n ruiter op ' $\mathrm{n}$ perd is, soos byvoorbeeld in Elisabeth Eybers se sonnet "Die vrou" (Die vrou en ander verse) met die beginreël: "Somer en herfs en winter trek in wye/ onafgebroke wisseling deur die land". In daardie sonnet lees ons van die dood as die "uitgeteerde ruiter". Of dink aan die ruiter van die dood in C.M. van den Heever se sonnet "Hoog op sy perd het hy doodstil gesit" (memoriam patris) of aan Van Melle se verhaal "Oom Daan en die dood", waar die persoon wat gaan sterf op 'n perd ry. Dadelik kan ons dan al sê dat die simbool (dikwels) iets konvensioneels is, iets algemeens. Waar gewone beeldspraak meestal iets partikuliers het, het die simbool dit (dikwels) nié. Daar is iets veralgemenends in die simbool, vandaar dat daar woordeboeke van simbole kan wees!

Dit wil egter nie sê dat alle veralgemening vanself simbolies is nie, want in Totius se "Trekkerslied" (Verse van Potgieter's trek en Uit donker Afrika) word die geval van die (Voor)Trekker veralgemeen tot die algemeen menslike trekker, maar in hierdie geval het Totius oudergewoonte weer besinnend in die gedig, reeds in strofe een, gesê almal se lewe is maar 'n trek. Totius was, terloops, geneig tot hierdie soort veralgemening, soos byvoorbeeld al klaar 
blyk uit titels soos "Die trein van die lewe" of "Alle vlees is gras"of "Die lewe soms 'n vloedstroomis" (Kursiverings in al hierdie gevalle is van my T.T.C.)

Die veralgemening in "Daar kom hul" is egter andersoortig, dit is simbolies. Dit is bowendien 'n sterk ironiese gedig, juis ten spyte van die Bybelteks as motto by die gedig, en ten spyte van die gebed en smeking van die moeder dat die kindertjies nie moet omkom nie. Ironies is ook die teenstelling vaderVader in die gedig: die kindertjies kla dat die vader met 'n klein letter nie meer daar is om hulle te beskerm nie, maar die moeder troos die vaderlose kinders dat die Vader daarbo nogal hulle gang reël! Tog kom die ruiters van die dood. Deur die simboliese, die veralgemenend-simboliese, groei die gedig verder uit tot die ironiese.

Van die beste nasionale gedigte van Totius is tegelyk simbolies (vergelyk hieronder "Die doringbome by die fontein"). Dink byvoorbeeld aan "Wie sal die land bewoon?" (Uit donker Afrika):

Wie sal die land bewoon?

wie in sy lengte trek?

wie sien sy wilde skoon,

of sterf by sy gebrek?

wie lewe by sy loon?

wie ander klanke wek

as dié van wreed-geskeurde wild,

somber in leeu se klou verstild?

Mens vra jou trouens af of dit ' $n$ nasionale gedig is, al staan dit in ' $n$ bundel met nasionale poësie. Dit gaan wesenlik in die gedig om die mens wat ly onder natuurlike geweld, en dan wel nêrens elders nie as in sy "woning", sy land. Weer eens gaan die simboliese saam met die ironiese; hierdie twee gee telkens, by Totius altans, dimensie aan mekaar. Dit gaan hier om algemene onherbergsaamheid. Die simboliese berus by Totius, soos by alle digters, op die algemene.

\section{Die algemene aard van die simboliese}

Hierdie algemene kan lê in die literêr-algemene, of kultureel-algemene, waaraan die woordeboeke oor simbole hulle bestaan te danke het. Maar dit kan ook 'n oeuvre-algemene wees - die groot digters veral is geneig tot 'n sekere soort herhaling, soos ons dit by Yeats of Adriaan Roland Holst of Van Wyk Louw, Opperman of Eybers en baie ander kry - ook by Totius. Vergelyk die beendere of voëls in Opperman se werk. Oeuvre-algemeen beteken dat sekere digters, veral die groteres, bestendige simbole het wat deurlopend in hulle gedigte voorkom, sê maar iets soos die kristal in Holst se werk, maar selfs in so 'n geval kan die oeuvre-algemene simbool op (iets van) die algemene simboliese waarde berus, soos byvoorbeeld die kristal in Roland Holst se gedigte, wat iets weg het van die algemene simboliek daarvan: 
"matter "exists' but as if it does not exist" (Cirlot, 1978:74), dit dui op "clarity", op "the place where God dwells", "immortality" (De Vries, 1974: 121). Dit is trouens 'n algemene verskynsel dat "the general symbolism has sometimes been narrowed ... to the particular, as often happens in traditional symbolism" (Cirlot, 1978:74 - partykeer behoort sulke tot die partikulier-verengde simbole tot 'n hele generasie, soos die beensimbool in 'n sekere periode by verskillende Engelse digters voorgekom het). In die geval van die algemene simbool verstaan ons die simboliek daarvan omdat dit deel is van ons algemene kulturele besit, dus ook van ons eie gees; in die geval van die meer private, partikuliere simbool, al is dit dan die partikuliere van die oeuvre- of generasiesimbool, verstaan ons dit omdat dit gereeld herhaal word en daardeur weer eens 'n soort konstante betekenis kry. Hoe dan ook, of dit die kultureel-algemene of oeuvre-algemene simbool is (wat gewoonlik iets weg het van die kultureel-algemene), ons verstaan die simbool, wat hom nooit self verklaar nie, altyd kon- en kotekstueel.

\section{Die voël as simbool}

Laat ons nou kyk na Totius se "Die roofvoël" (Uit donker Afrika):
Met breë swier en swaai
van vleuelslag het hier
'n roofvoël neergestryk, die kop diep-in, dan hier, dan daar sy blik gewénd en skadu neer laat stryk.
Oor velde van smarag, die heuwels uit en oor wat slaap in sonnige vree, het hy geroei; dit was by neerslag van sy vlerk 'n swart doodskaduwee!
Verdrywend het hy op sy prooi ook neergeskiet langs Vaalrivier se wal, waar al wat mens is, vlug soos kuikens voor die valk; en wat nie vlug, moet val.

Ons vind dat die voël soos die woning of die boom herhaaldelik in Totius se werk voorkom. Hierbo is gewys op die dood deur geweld in Totius se poësie. Meermale kom die voël deur gewelddadige dood om in sy werk, soos die klein voëltjies in "Die wêreld is ons woning nie", of die voël in "Die tarentaal", of daar is die kat as die "voëltjiemoordenaar" in "Is dit geen ware vrede dié" (Skemering). Die duif is soos in die algemene simboliek ook by Totius simbool van die siel, soos in "Weer in die ark".

Gesien teen die agtergrond van sy eie werk, is dit nogal ironies dat die voël in Totius se "Die roofvoël" die moordenaar is in plaas van die vermoorde. 
Weer weet ons uit die bundelkonteks dat "Die roofvoël" 'n gedig is wat betrekking het op die nasionale geskiedenis en dat dit hier die swart man is wat in 'n oorlogstryd gewikkel is met die blanke - met die Trekker. Tog kan ons die gedig op twee maniere lees. Ons kan dit losmaak uit sy een konteks, dié van die bundel, en dit in 'n ander plaas: ons kan dit plaas in die konteks van 'n redelik algemene siening van die voël as moordenaar, soos ons dit byvoorbeeld teenkom by Van Wyk Louw, in sy "Arend" (Gestaltes en diere), of by P.W. Buys in sy "Arend" en "Aasvoëls" (albei in Wit korbeel), of as kwade teken in Van den vos Reynaerde of in die folkore (die uil byvoorbeeld). Maak dit saak dat Totius sy roofvoëlgedig ruimtelik situeer aan die Vaalrivier? Sekerlik nie. Veralgemening skep simboliek, maar verbesondering, partikularisering hoef dit nie te vernietig nie. Tog kan 'n sekere manier van verbesondering die simboliese in sekere gevalle tot niet maak. Daar is reeds daarop gewys dat Totius geneig was om, soos dit algemeen bekend is, deur sy toepassings te veel te verbesonder, deur te veel sy beeld op net een saak te betrek, waardeur hy dus te min veralgemeen.

\section{Simbolisering as vervaging, vermenigvuldiging}

Simbolisering beteken in sekere opsigte vervaging; vervaging in die sin dat ons die simbool nie altyd rasioneel en definitief kan bepaal nie. Dit is ' $n$ vermenigvuldigende, verdienstelike vaagheid van die simboliese. 'n Goeie voorbeeld is "Nag op die see" van Totius:

(Digby Aden)

Dis álles see en álles donkerheid, soos toe die aarde woes en ledig was en nag gesweef het oor die wêreldplas.

Geen horison of ster is sigbaar meer; geen teken waar die oog op af kan gaan; ek hoor net teen die skip die golwe slaan.

Tog vaar hy immer voort, hy vaar nou blind, die voorpunt teen die donkerte gerig.

Op die kompas alleen val bundels lig!

Dit is 'n goeie simboliese gedig, ondanks die subtitel ("Digby Aden") wat Totius daaraan gee. Die gedig het met Aden of met geen ander besondere ruimte veel te make nie. Die gedig se veralgemening weerspreek sy eie partikulariserende subtitel. Dit is simbolies ook ondanks die vergelykende tweede versreël waarin Totius sê die donkerheid van die see is "soos toe die aarde woes en ledig was". Daardie "soos" sluit die simboliese van die gedig nie uit nie. Waarin lê die simboliese? In die slot, in die kompas wat, in teenstelling met die totale duisterheid van die begin af, onder die lig van bo/Bo lê en die koers bepaal. Wat is die simboliese inhoud van die gedig? Min of meer (omdat dit simbolies is, juis min of meer) die volgende: iets, wat ook 
al, die mens, die aarde, kan soos 'n skip (mens moet noodwendig vergelyk as jy die simboliese wil uitlê) koers hou, al is dit in die donker (in die onsekerheid, die onsienlike, die abstrakte, ensovoort). Of: te midde van die onsienlike (waaroor Totius dit dikwels het) is daar tog magiese hulpmiddels of sienlike, "oogbewyslike" hulpmiddele (lees "Geloof" in Passieblomme); te midde van die abstrakte is daar tog konkreta wat help, soos die konkrete bewys, oogbewys, in "Eerste botsels" in Passieblomme, waar die lentebotsels in die natuur bewys dat daar opstanding uit die dood is. Die kompas kan die redelike wees, die geloof, die Albestier, enige hulp van buite. Daar is nog talle ander implikasies: die reddende kleinheid van die kompas teenoor die oorweldigende grootheid (skip, see, en dergelike. Vergelyk die rympaar wêreldplas/kompas wat hierdie teenstellig uitlig). 'n Ander simboliese inhoud is: die so menslik bekende teenoorgesteldheid, soos blyk uit die kontras: donkerheid (vs.1) - lig (slotvers). Of die gedig simboliseer die algemeen bekende verskil tussen die horisontalisme (die see) en die vertikalisme (die lig wat op die kompas val), waar laasgenoemde dan die reddende faktor is. Die simboliese is, anders as die direk beeldende, nie duidelik omlyn nie, en daardeur meestal ryker.

Dit is moontlik om nog enkele ander simboliese implikasies in "Nag op die see" uit te lig, eerstens om daarop te wys dat egte simboliek iets veelvoudigs is, tweedens om te probeer aantoon dat die simboliese dikwels berus op die konvensionele, die algemene, die universele. Die simboliese denke/voel/wil is kollektief (onder- of onbewus). Totius se "Die weg" (Ragel) is nie 'n goeie voorbeeld van 'n simboliese gedig nie, maar dit is waar wat Totius daar van die simbool sê: dit (naamlik die weg as simbool) is "aan almal bekend" daarom verstaan ons die simbool onmiddellik, al sou ons dit nie volledig in al sy implikasies verstaan nie - die simbool wat vanself en onmiddellik kommunikeer.

\section{Veelvoudigheid van die simbool}

So konvensioneel of universeel is die simboliek van Totius se "Nag op die see" dat ons weer na Cirlot (1978) en na De Vries (1974) kan gaan en daar talle sake sal vind wat netjies van toepassing is op Totius se gedig - byvoorbeeld wat die skip betref. Trouens, ons kan na die literatuur self gaan en sien hoe die skip in talle gedigte voorkom in min of meer dieselfde simboliese onderskeidinge as in Totius se gedig.

\subsection{Die skip as simbool}

Die skip kom al voor by Homeros (in die Odusseia), of in die mite van Charon wat die dooies in sy boot oor die Styx en Acheron gevoer het, of by Holst, of by Van Wyk Louw (dink net aan Dias), of by Opperman, met simboliese 
onderskeidinge soos ons dit ook by Totius teenkom, nie net in "Nag op die see" nie maar ook in ander gedigte, byvoorbeeld "Weer in die ark" of "'n Skuitjie op die see". Cirlot en De Vries sê dat die skip die transenderende simboliseer (die "Ship of Transcendence"), "the desire to transcend existence - to travel through space to the other worlds" (Cirlot, 1978:294). In De Vries (1974:420) se formulering: "Transcendence as sailing to the 'other world"', na die "heaven-haven", na die "Harbour of Salvation", "a voyage to the Other World". De Vries praat van "rising above mere existence" deur die reis met die skip. Cirlot praat in verband met die skip van "the symbolism of verticality", en dit is presies wat ons in "Nag op die see" kry, waar die lig vertikaal van bo/Bo op die kompas val, en dit sou gepas wees vir Totius dat die skip hier, soos in die konvensionele simboliek, die terugkeer van die siel is (dink weer aan Charon), die ontsnapping uit ongunstige, chaotiese, aardse omstandighede soos in "Weer in die ark" en soos ook in Opperman se "Digter" (Negester oor Ninevé). Dat die skip redding bring ("salvation"), pas heeltemal in die simboliese wêreld van Totius, en "in Christian symbolism, the ship represents the Church" (Cirlot, 1978:249). Ook De Vries wys daarop dat die skip die Kerk simboliseer. De Vries noem ook die skip as simbool van die liggaam wat die siel dra: "ships are symbols of the human body carrying the soul", wat ook van toepassing is op Totius se gedig, waar die lig dan die gees, siel of selfs intellek of wil kan wees wat die liggaam lei. Dink ook daaraan dat die Egiptenare skepe vir 'n hiernamaalse reis saam met hulle gestorwe vorste begrawe het. De Vries noem nog ander simboliese onderskeidinge van die skip: "immortality", "resurrection". Dit word alles genoem, nie alleen om daarop te wys hoe die digter in sy simbole aansluit by die algemene, konvensionele of universele nie, maar ook om 'n aanduiding te probeer gee van die veelvoudigheid van die simbool.

Die see is naas die skip 'n tweede simboliese motief in "Nag op die see", wat alleenheid, chaos simboleer (De Vries, 1974:420), en wat ons teenkom in baie ander gedigte, daardie "drifting indefinite bitterness of life" (by Yeats, byvoorbeeld).

Die kompas, ten slotte, is 'n derde simboliese motief, wat "spiritual illumination" (De Vries, 1974:420) simboliseer.

\subsection{Die boom as simbool}

'n Ander voorbeeld van 'n eenvoudige simboliese gedig van Totius is "Die doringbome by die fontein" (Uit donker Afrika):

Daar staan hul nou, die swart gestaltes, bome

al krom en skeef, dig teen mekaar en oud.

Die son gaan weg, hul vang in donker drome

van winterslaap die laaste sonnegoud. 
Ek het hul lief, die dorings wat verbleek het; ek het hul lief, die stamme swart, ontdaan, meer as die plant wat mensehand gekweek het en in die tuine as pronkgestaltes staan.

Soos hul daar staan in naadrende awendvrede, diep in die holte en teen die helling aan, sing hul vir my uit groue voor-verlede die stemmingslied van donker voorbestaan.

Hul is geen plant van weelde of hoër orde, maar eie kinders van ons vaderland.

Waar ander kruid moes sterf, het hul geworde, in sonnevuur wat oor die velde brand.

Die wilde dier wat vry is op sy togte, wat trap en pluk, het hulle nie verskoon. Van eeuestryd getuig die knoeste en bogte; die takke, al styf, dra nou 'n doringkroon.

Maar kyk, hul leef in groepies langs die hange waar hul geruis van water-are hoor, en stuur hul wortels langs verborge gange wat na die laaste waterdruppel boor.

Al kom die voorjaar met 'n droë asem, tog is hul diepte daar 'n lusvertrek; dan waai uit hul 'n geurige blommewasem wat in my hart 'n stemmige vreugde wek.

Weer eens steun die simboliek van hierdie gedig op 'n algemene, universele, kollektiewe of konvensionele simboliek, in so 'n mate dat ons nog duideliker as in die vorige geval na die woordeboeke kan gaan (immers: simbole is woordeboekmateriaal) om daar 'n uitleg vir die simboliek van Totius se gedig te vind. Hierdie keer lyk dit amper daarop of Totius die voorskrif van die universele simbool van die boom nagevolg het! Daar is 'n verstommende ooreenkoms tussen wat in Cirlot en De Vries oor die boom as simbool staan en wat ons in Totius se gedig vind - of omgekeerd gesien, lyk dit of Cirlot en De Vries Totius gelees het! Byvoorbeeld: die woordeboeke oor die simboliek van die boom wys daarop dat die boom drie strukturele dele het, om dit so te noem, naamlik die wortels, die stam en die blare. Al drie kom woordeliks en presies so by Totius voor. Cirlot (1978:346) noem "the 'three worlds': the lower world . . ; the middle world: earth; the upper world: heaven ... It is interseting to note that the three worlds of tree-symbolism reflect the three main portions of the structure of the tree: roots, trunk and foliage". Presies so vind ons dit by Totius: "roots" - die bome "stuur hul wortels langs verborge gange/ wat na die laaste waterdruppel boor"; "trunk" - daar is "die stamme swart, ontdaan"; "foliage" - daar is die blomme met hulle "geurige blomme'wasem". Dit is of die digter die konvensie napraat. De Vries (1974:473) noem dieselfde simboliese onderskeidings as Cirlot (en dat hierdie twee bronne so eenders lui, bevestig die algemene aard van simbole - mens vra jou af hoe die eis van vernuwing wat so dikwels aan die poësie gestel word, geld vir die simbool): die boom "connects the three worlds: its roots are in the under- 
world, its trunk on earth, and its foliage in heaven". Weer eens presies Totius. De Vries sê soos Cirlot van die boom: "it connects the three worlds". Die volgorde waarin Totius hierdie drie struktuureenhede van die boom noem, is belangrik: hy begin in strofe twee by die sigbare, die stamme, en in die twee laaste strofes kom vervolgens die onsigbare twee ter sprake: eers die wortels wat na onder boor en ten slotte die blomme wat na bo reik. Dit alles lyk weer op wat Cirlot sê: "The tree, with its roots underground and its branches rising to the sky, symbolizes an upward trend". Ons kry hier met ander woorde dieselfde vertikalisme as in "Nag op die see". Verder nog Cirlot (1978:346): "in its most general sense, the symbolism of the tree denotes ... growth (Totius praat juis van die bome se "geworde" in 'n wêreld waar ander plante sterf), proliferation, generative and regenerative processes. It stands for inexhaustible life (dink terloops ook aan "Die besembos") ... immortality" - dit alles is van toepassing op Totius se bome, waarvan ons baie familie in die poësie kan uitwys, byvoorbeeld Buys se "Wynstok" (Pleroma), wat ook in die aarde staan maar in die hemel in rank. De Vries (1974:473) noem as simboliese waardes van die boom verder nog: "organic unity (let op hoe Totius se bome bymekaar staan, as 'n eenheidsgroep), health (die taai bome van Totius), longevity" (Totius se bome is beslis oud en oorlewend).

Ten slotte nog die volgende wat Cirlot (1978:346) sê (en wat dalk nogal een van die maniere is om die konvensionele simbool te vernuwe): "As is often the case with symbols, many more specialized meanings have been developed on the basis of the general tree-symbolism": by Totius is hulle spesifiek bome van sy vaderland - waardeur hy dalk wil sê: daar kan 'n versoening wees tussen die nasionale en bo-nasionale (wat in Joernaal van Jorik van Opperman nie die geval is nie).

\section{Beeld en simbool}

Die eienaardige is dat die beeld wat homself in die gedig ekspliseer, soos Totius dit dikwels gebruik, in die literêre teorie oor die algemeen as struktureel minder heg en waardevol beskou word as die simbool. Wat die begryp van albei betref, is die verskil alleen dit, dat die beeld intratekstueel (kotekstueel) begryp word en die simbool ekstratekstueel of selfs intertekstueel. Dit lyk of ons versigtig moet wees om dit sonder meer met kommunikatiewe waarde te verbind. Die beeld staan binne sy eie konteks, die simbool staan binne ' $n$ vreemde of uitwendige (algemene) konteks. Die beeld verduidelik homself, die simbool moet sy verduideliking van buite (van die algemene) kry - maar word in die algemeen nietemin as die betere beskou.

Vanweë sy sintetiserende, multivalente aard is die simbool een van die elemente wat aan die gedig waarde $k$ an gee, maar ons moet tog versigtig omgaan met die waardebepalende aard van die simbool. Die simbool is nie sonder meer beter as byvoorbeeld die geëkspliseerde beeld, of as die allegorie 
nie. Is van die grootste literêre werke wat ons ken dan nie allegorieë of allegories nie, terwyl van die slegstes simbolies is? Dink aan allegorieë soos Elckerlyc, of Pilgrim's progress, Roman de la rose, Palamedes, Jan, Jannetjie en hun jongste kind, Verwey se Rouw om het jaar of selfs Gorter se Mei wat deur party as 'n allegorie beskou word - party hiervan word as groot klassieke werke beskou. En is Totius se "Die Godsbesluit" nou 'n mindere gedig omdat dit sy beeld ekspliseer en toepas? Sekerlik nie - dit is nie vreemd nie dat hierdie gedig een van daardies is wat ons onmiddellik met sy naam assosieer, soos ons "Winternag" onmiddellik met Marais assosieer of "Die vlakte" met Celliers. Trouens, hierdie gedig se selfeksplisering lê nie, soos algemeen betoog word, soseer daarin dat die boom eers beskryf word en die toepassing daarna eksplisiet gegee word nie - dit lê reeds in die titel: die titel praat van die Godsbesluit, die gedig begin egter met die beskrywing van 'n boom, nadat die titel ons daarop voorberei het dat hierdie boom nie (net) 'n boom is nie; sonder die eksplisiete toepassing in die $3 \mathrm{e}$ strofe (na 'n asterisk) dat die doringboom beeld van Gods Raadsbesluit is, sou ons nog altyd 'n eksplikasie gehad het, danksy die titel - en baie simboliese gedigte in die literatuur word op hierdie wyse deur hulle titels verraai. (Daar bestaan blykbaar nie 'n studie wat vir ons die spesifiek simboliserende funksie van titels verduidelik nie.)

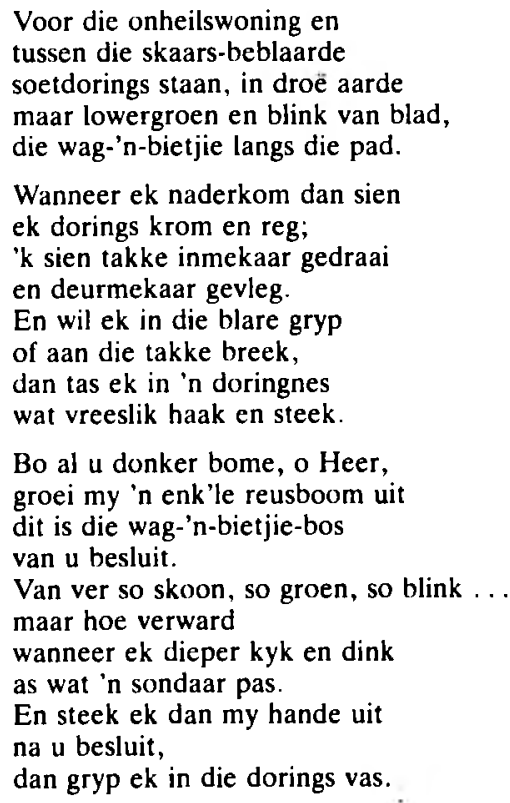

In 'n sekere $\sin$ is die simbool egter weliswaar beter as die gewoon vergelykende, allegoriese, beeldsprakige gedig, omdat die simboliek verrykte, gesintetiseerde betekenis is, soos hierbo aangedui is. Die literêre of literariteit van die gedig lê daarin dat dit met die minimum middele die 
maksimum sê, of, soos mens dit ook kan formuleer: een element in die gedig kan meer as een ding sê, of: die gedig sê dit wat hy wil sê op meer as een manier: wat die gedig kommunikeer, sê hy nie net semanties nie maar ook fonies, ritmies, ensovoorts, en reeds wat hy semanties sê, sê hy alleen al op meer as een manier, deur meerduidigheid, dubbelsinnighed, ambivalensie, multivalensie, en dergelike. Dit is presies wat in die simboliese gedig gebeur, soos ons hierbo gesien het. Maar: 'n gedig se multikommunikatiewe vermoë lê nie net in die simboliese nie, en daarom is dit nie die simboliek alleen wat 'n gedig beter of ryker of hegter makk nie. Gedigte soos "Die oue wilg" of "Ter nagedagtenis van" is tipiese gevalle waar Totius sy beeld ekspliseer: in die eerste beskryf hy die wilgerboom en sê dan later: "o Wilgerboom/ beeld van my skuld ...", en in die tweede spreek hy die Mooiriver aan as "ewebeelt'nis van" 'n vrou se lewe - dit is twee swakker gedigte, egter nie om hulle eksplisering van die beeld nie maar gewoon omdat dit in verskeie ander opsigte swak is. "'n Sprokie" beskryf ook eers sy saak, die duif, en dan sê die digter weer ekspliserend: "So is daar somber siele/ waar hy my aan laat dink", en tog is hierdie (weer naïewe) gedig nie onaardig nie.

\section{Die eenvoudige beskrywende gedig}

'n Gedig kan nog onder die vlak van die simboliese bly en tog nog goed wees. Om dit te illustreer, is daar die gedig wat verwant is aan "Nag op die see", naamlik "In die Rooi See", en ons kan die twee naas mekaar lê (hulle staan trouens in die bundel Skemering direk by mekaar): "In die Rooi See" is 'n eenvoudige gedig, 'n beskrywende gedig, 'n toepassingsgedig, en tog goed, en nie minder goed as "Nag op die see" nie. Met sy sestien verse (vier strofes) bly dit gewoon beskrywend tot en met die veertiende, dan kom die vergelyking in die twee slotverse, 15 en 16: net soos die meeue saamvlieg met die boot, so vlieg die bemindes se gees met die reisiger saam. Dit is 'n konkretiserende beeld, raak, goed, en dit sê op sy eenvoudige manier tog ook meer as een ding: wat in die natuur gebeur, gebeur ook in die menslike gees. Daar is sekere korrespondensies tussen mens en natuur, sê die gedig. Terug is ons by die veralgemening, al is dit hierdie keer in 'n gedig wat mens nie ' $n$ simboliese sal noem nie. Intussen kan mens toegee dat die eg simboliese gedig ryker kan wees as die bloot vergelykende, maar nie noodwendig nie. Eenvoudige, konkreet beeldende gedigte het net soveel reg as die diep simboliese. Ons moet nie vergeet nie dat Van Wyk Louw op 'n keer in een van sy gedigte gesê het dat die diepte kan bedrieg. En ons moet nie vergeet nie dat ons 'n gedig of enige literêre werk altyd moet beoordeel op grond van sy totaliteit, nie net op grond van dit of dat alleen nie. Selfs die gewoon beskrywende vers kan mooi en goed wees, sonder dat dit enige diepte wil bereik. Van die mooiste gedeeltes in Trekkersweeis niks meer as beskrywend nie, byvoorbeeld 1.iii: "Verlore klein lê op die Rand/ hul huisie in die trekkersland". In Passieblomme is daar in verskeie gevalle versreëls wat dadelik 'n indruk makk, en dan is dit dikwels 'n vers of verse wat geen simbool 
of selfs geen beeld of vergelyking bevat nie maar 'n direkte uitspraak, soos: "ons bly aan die wordende oomblik gebonde", of: "Jou kind is dood met 'n vreeslike dood", of: "'n asempie wind kon haar vlerkies breek" (met die verskole beeld van sê maar 'n vlinder). Of dink aan 'n strofe soos: "Wat is die herder dan wat skaars beskut/moet wegskuil in sy brose herdershut;/ en wat die man wat oor die vlakte ry,/ of werkers wat langs die pad in tentjies bly?" in "'n Sondagsbee", of later die vers: "Dink, Heer, wat in die wolk u bliksems wend,/aan wie dán vlug of wegskuil in hul tent". As daar in "Ag, sy het nie gesterwe" staan: "Ag, sy het nie gesterwe,/ maar sy was sommer dood", is dit beeldloos, asimbolies, dit is sommer gesê, en aangrypend gesê. Van party van die beste gedigte in Passieblomme geld dit in hulle geheel dat hulle sommer gesê is, soos "Ek het gesoek". Of daar is die gedig "Waar huisies staan", een van die bestes in Passieblomme, ook so 'n sommergedig. Dieselfde kan gesê word van "Ek wou so graag 'n liggie sien", of "Veldeensaamheid", of "Eensaamheid". 'n Mens wil amper sê dit is gedigte wat bevry is van die simboliese. En dan dink mens daarby ook daaraan dat dieselfde Totius wat soms so erg oorspanne en retories kon skryf, tegelyk van die eenvoudigste, goeie gedigte geskryf het. En ons dink dan daaraan dat Ingrid Jonker later gekom het en doelbewus sulke sommergedigte geskryf het. Ten slotte nog "Ek het gesoek". Die wa in hierdie gedig is geen simboliese wa of kwasisimboliese wa of beeldsprakige wa soos elders by Totius nie: dit is sommer'n wa en daarom so effektief in die gedig. Waar dit Totius soms verwyt is dat hy sy simbole te veel verduidelik, wys hy in 'n gedig soos hierdie dat hy sonder die simbool nogal goed kon klaarkom!

Selfs 'n direkte toepassing kan nog altyd uitloop op 'n goeie gedig, soos in die geval van "Aden" (Skemering), en met dan nogal die toepassing van 'n algemene waarheid: "die dorste berge is naaste aan die see!"

\section{Simbolies praat}

Hoe ons die simbool presies begryp, is nie baie duidelik nie. Dit is moontlik dat die sielkunde ons hier iets kan leer van die kollektiewe, on- of onderbewuste begryp, die argetipiese begryp, wat dalk tog dan 'n soort dieper begryp is, 'n omvangryker een, maar oergerig, atavisties. Die simboliese begryp is waarskynlik soos Totius in "Die digter as siener" sê "onmiddellik".

Deur die kollektiewe begryp van die simbool word die digkuns dalk tog die terrein waar ons as mense saamdink, en al praat 'n digter dan van homself, praat hy tog nie sy eie praat nie. Die digterlike ek is 'n simboliese ek.

\section{Bibliografie}

Cirlot, J.E. 1978. A dictionary of symbols. Londen: Routledge \& Kegan Paul. 
De Vries, A. 1974. Dictionary of symbols and imagery. Amsterdam: North Holland Publishing Company.

Du Toit, J.D. (Totius). 1977. Versamelde werke 10. Kaapstad: Tafelberg.

Potchefstroomse Universiteit vir C.H.O. 